\title{
Yield and Fruit Characteristics of Various Apricot Cultivars under Subtropical Climate Conditions of the Mediterranean Region in Turkey
}

\author{
A. Aytekin Polat and Oguzhan Caliskan \\ Department of Horticulture, Faculty of Agriculture, Mustafa Kemal University, Antakya, 31034 Hatay, Turkey \\ Correspondence should be addressed to A. Aytekin Polat; apolat@mku.edu.tr
}

Received 19 March 2013; Revised 29 June 2013; Accepted 30 June 2013

Academic Editor: Robert J. Kremer

Copyright (C) 2013 A. A. Polat and O. Caliskan. This is an open access article distributed under the Creative Commons Attribution License, which permits unrestricted use, distribution, and reproduction in any medium, provided the original work is properly cited.

\begin{abstract}
Seven apricot cultivars ("Beliana," "Canino," "Precoce de Colomer," "Feriana," "Rouge de Sernhac," "Tokaloğlu," and "Macar") were evaluated at the experimental orchard of the Department of Horticulture, Faculty of Agriculture, Mustafa Kemal University, Hatay, Turkey. Phenological and pomological characteristics such as flowering period, average fruit weight, yield, fruit dimensions, flesh/seed ratio, acidity, and total soluble solids (TSSs) were examined. In addition, yield parameters of the cultivars were evaluated. Over four years, the highest average fruit weight was obtained from "Rouge de Sernhac" ( $37.9 \mathrm{~g})$, while "Feriana" had the lowest (30.9 g). The flesh/seed ratio was the highest in the "Canino" (16.8). "Canino" had the highest TSS content with $14.5 \%$, whereas "Beliana" had the lowest TSS value with 10.6\%. "Beliana" and "Feriana" ripened the earliest (May 20) while "Precoce de Colomer" ripened latest (June 7). The average yield was highest on "Rouge de Sernhac" (41.2 kg/tree). "Beliana" and "Feriana" cultivars are recommended for precocity, and "Rouge de Sernhac" and "Tokaloğlu" for middle season in Dörtyol, Turkey.
\end{abstract}

\section{Introduction}

More than $80 \%$ of apricot (Prunus armeniaca L.) production comes from the Mediterranean area and is concentrated in a period of 30-40 days, mostly in June [1]. Turkey is the world's largest producing country of both fresh and dried apricot. Apricots are grown in almost all parts of Turkey, except in the very humid regions around the Black Sea and in the high plateaus of the East Anatolian Region [2]. Most production is drying cultivars whereas fresh apricot cultivars are produced primarily in coastal regions, especially the Mediterranean and Aegean Sea regions of Turkey [3]. In Turkey, apricot is grown in a wide range of climatic conditions. Weathers are very cold during winter and very arid during summer in main apricot growing areas: Malatya, Erzincan, and Iğdır provinces. Apricots grown in these provinces damaged frequently by late spring frost. However, the climate of Mediterranean region which have semiarid, having hot summers and mild-winters can be occurred rarely frost damage [4]. Hatay, which is located in the eastern Mediterranean coast of Turkey, has the most suitable ecological conditions for growing table apricot. Apricot planting in Hatay area has increased rapidly due to the comparative advantage of earliness of harvest.

In Turkey, strong market demand, along with the introduction of foreign cultivars, opens up promising possibilities to extend the cropping season to May and June. Breeding programs for the improvement of local cultivars, together with the introduction of high-quality cultivars from Greece, France, Italy, Spain, and USA, are currently introduced to Mediterranean region of Turkey and are under evaluation. Fruits in Turkey are harvested 15-30 days earlier as compared to the country of origin $[3,5]$. Bassi and Audergon [6] reported that some cultivars from Italy seem to perform well in terms of size and appearance or taste, although they often show reduced yields owing to their poor adaptability to the climate and soils of the region. Therefore, new cultivars need to be evaluated and selected that can perform well on a commercial scale under local environmental conditions.

The problem of environmental is inadaptability of new varieties to different conditions from those of their origin. 
Fruiting regularity is a serious problem in several apricot cultivars. The cultivars flower irregularly and sufficiently in environments other than those of origin. The climaticenvironmental factors may heavily influence the breaking of flower bud dormancy, also affecting the entity of the appearance of floral anomalies. Also apricot culture is greatly restricted by climatic conditions, especially those related to chill accumulation in several growing areas, with a significant influence on productivity $[7,8]$.

The aim of this study was to evaluate blossoming times, fruit quality traits, and yield parameters of some foreign and domestic apricot cultivars for their suitability for cultivation in Dörtyol (Hatay), Turkey, conditions.

\section{Materials and Methods}

The study was conducted at the Mustafa Kemal University, the Faculty of Agriculture, Dörtyol Research Station in Hatay, Turkey. Dörtyol Research Station is located at $36^{\circ} 13^{\prime} \mathrm{E}, 36^{\circ}$ $54^{\prime} \mathrm{N}, 198 \mathrm{~m}$ a.s.l. Dörtyol has a typical Mediterranean climate; the yearly average temperature is $19.3^{\circ} \mathrm{C}$, with $925 \mathrm{~mm}$ precipitation, which primarily falls during winter and spring. Dörtyol has 521 winter chilling hours (below $7^{\circ} \mathrm{C}$ ). The data were obtained from 33 years of meteorological observations. The temperature, precipitation, and humidity values during of the study are also shown in Figure 1.

This study was designed using six foreign ("Beliana," "Canino," "Precoce de Colomer," "Feriana," "Rouge de Sernhac," and "Macar") and one native ("Tokaloğlu") cultivars which are used for fresh market consumption. Seven apricot cultivars were grafted onto seedling rootstocks and planted with $6 \times 6 \mathrm{~m}$ in 1997 and trained in an open-vase system. The orchard soil is clay textured, and the experimental field was irrigated by drip irrigation.

2.1. Phenological Observations. Different phenological properties (first blossoming, full blossoming, end of flowering, and ripening period) were evaluated. First and full blooms were based on $5 \%$ and $70 \%$ open flowers, respectively. The end of flowering was based on $90 \%$ petals drop. The ripening period was the period between the first and the final harvest dates.

2.2. Pomological Characteristics. Fruits were harvested at maturity based on appearance and taste, and 30 fruits were randomly sampled from each tree. Pomological characteristics (fruit weight, fruit dimension, flesh/seed ratio, soluble solid, and acidity contents in fruit juice) were evaluated. Each fruit was weighed. The width and length values of each fruit were measured by a digital compass. The flesh/seed ratio was estimated as follows: ((mean fruit weight - mean seed weight)/mean seed weight). Total soluble solids (TSSs) were determined using a hand refractometer, and acidity was measured using a digital burette. $\mathrm{pH}$ values of the fruit samples were obtained by a digital $\mathrm{pH}$ meter.

2.3. Vegetative Growth and Yield Parameters. The vegetative growth of the cultivars was evaluated by measuring the annual increase of trunk diameters and lengths of annual shoots on vegetative branch. Productive parameters of the seven cultivars such as cumulative production per plant (kg) and cumulative production per hectare (tons) were calculated.

2.4. Data Analysis and Statistics. A randomized experiment was designed with five trees from each cultivar, and each tree was treated as one replicate. Variance analyses of the data were conducted and the mean comparisons were made by Tukey's honestly significant differences (HSD) test where $P$ value less than .05 was considered to be significant [9].

\section{Results and Discussion}

3.1. Phenological Observations. The flowering stages of the apricot cultivars are shown in Figure 2. "Beliana" was the earliest cultivar to bloom, and "Rouge de Sernhac" and "Macar" were the latest. Full bloom periods of the cultivars ranged between March 11 and March 23.

Early production is of the very important for growing fresh apricot in the Mediterranean region of Turkey. The earliest maturing cultivars were "Beliana" and "Feriana" (May 20) whereas the latest ripening cultivars were "Precoce de Colomer" and "Macar" (June 7) (Figure 3). In the previous studies, the ripening data for apricot cultivars were in the range of May 14-June 26 in Spain [10], June 11-September 10 in Hungary [11], and May 26-June 25 in Italy [1]. The eastern Mediterranean region is the earliest apricot producing area in Turkey. This result could be due to climatic conditions in the region, where the climate is semiarid, having hot summers and mild winters. This area had high day-night temperature changes from February to May $\left(>20^{\circ} \mathrm{C}\right)$ and maximum temperatures were $>30^{\circ} \mathrm{C}$ in April and May (Figure 1). Therefore, the apricot cultivars could be early fulfilling degree-day thresholds from full bloom to ripening in Dörtyol conditions. Ruml et al. [12] indicated that the effect of growing degreeday thresholds on harvest time of apricots is very important for each apricot-producing region.

3.2. Pomological Characteristics. The differences among the fruit quality characteristics of the cultivars tested were statistically significant at 0.05 levels. The fruit size is one of the most important fruit quality traits for fresh apricots. Over four years, "Rouge de Sernhac" had the highest average fruit weight, fruit width, and fruit length $(37.9 \mathrm{~g}, 39.5 \mathrm{~mm}$, and $41.6 \mathrm{~mm}$, resp.), whereas "Tokaloğlu" had the lowest (30.8 g, $34.7 \mathrm{~mm}$, and $36.3 \mathrm{~mm}$, resp.) (Table 1). Our data concerning fruit weight was higher than those found by Polat et al. [3] and Polat and Yilmaz [13] in "Canino," "Feriana," and "Precoce de Colomer." The fruit height of "Precoce de Colomer" and "Rouge de Sernhac" cultivars was highest (39.4 and $38.5 \mathrm{~mm}$, resp.). The previous studies on apricot also indicated a high variability among apricot cultivars regarding fruit size characteristics [10].

"Precoce de Colomer" had the highest seed weight $(2.8 \mathrm{~g})$ whereas "Canino" had the lowest $(1.9 \mathrm{~g})$. The flesh/seed ratio of the cultivars was highest for "Canino" (16.7) and lowest for 


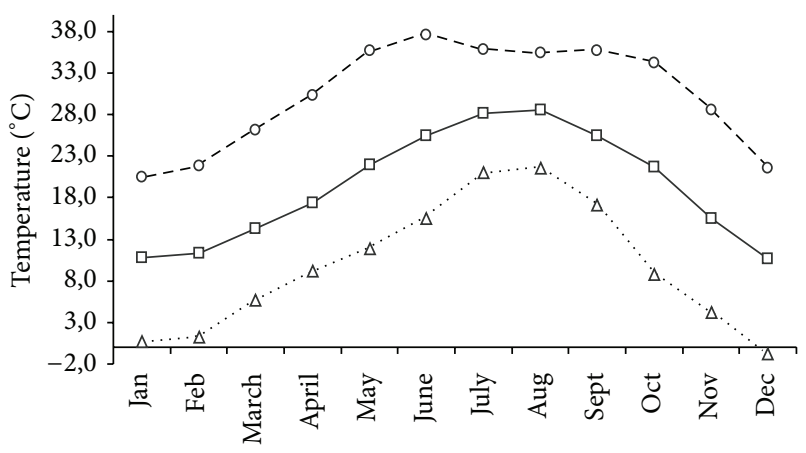

(a)

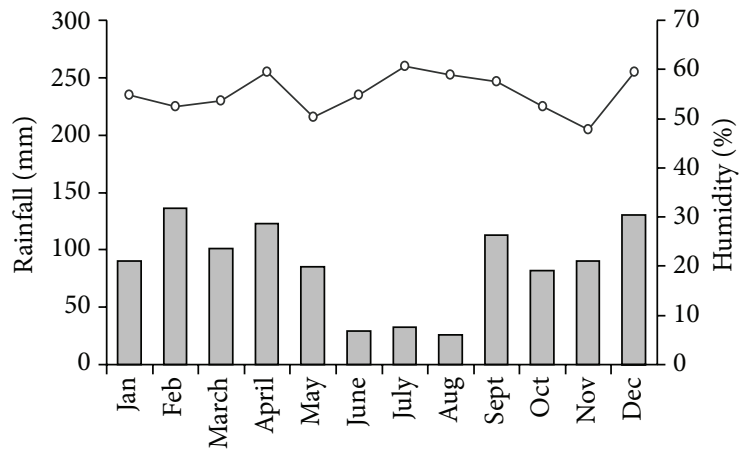

(b)

Figure 1: Meteorological data for Dörtyol, Hatay, in the eastern Mediterranean region of Turkey. (a) Minimum $(\Delta)$, maximum $(\mathrm{O})$, and average temperatures $(\square)$ and (b) rainfall level (grey columns) and mean humidity $(\mathrm{O})$ in growing years.

TABLE 1: Some fruit quality characteristics of the apricot cultivars (average of four years).

\begin{tabular}{|c|c|c|c|c|c|c|c|c|c|}
\hline \multirow{2}{*}{ Cultivar } & \multicolumn{4}{|c|}{ Fruit } & \multirow{2}{*}{ Seed weight (g) } & \multirow{2}{*}{ Flesh/seed ratio } & \multirow{2}{*}{ TSS (\%) } & \multirow{2}{*}{$\mathrm{PH}$} & \multirow{2}{*}{ Acidity (\%) } \\
\hline & $\begin{array}{l}\text { Weight } \\
\text { (g) }\end{array}$ & $\begin{array}{l}\text { Width } \\
(\mathrm{mm})\end{array}$ & $\begin{array}{c}\text { Length } \\
(\mathrm{mm})\end{array}$ & $\begin{array}{c}\text { Height } \\
(\mathrm{mm})\end{array}$ & & & & & \\
\hline Beliana & $33.1 \mathrm{ab}$ & $36.0 \mathrm{~cd}$ & $38.2 \mathrm{~b}$ & $35.0 \mathrm{c}$ & $2.4 \mathrm{ab}$ & $10.7 \mathrm{~d}$ & $10.6 \mathrm{e}$ & $3.29 \mathrm{a}$ & $1.72 \mathrm{~b}$ \\
\hline Canino & $34.7 \mathrm{ab}$ & $37.3 \mathrm{abc}$ & $38.8 \mathrm{ab}$ & $37.5 \mathrm{abc}$ & $1.9 \mathrm{c}$ & $16.7 \mathrm{a}$ & $14.5 \mathrm{a}$ & $3.14 \mathrm{ab}$ & $2.06 \mathrm{ab}$ \\
\hline Feriana & $30.4 \mathrm{~b}$ & $36.5 \mathrm{bcd}$ & $37.8 \mathrm{~b}$ & $36.8 \mathrm{abc}$ & $2.4 \mathrm{ab}$ & $11.4 \mathrm{~cd}$ & $11.4 \mathrm{cde}$ & $3.16 \mathrm{ab}$ & $1.88 \mathrm{ab}$ \\
\hline Macar & $33.7 \mathrm{ab}$ & $38.6 \mathrm{ab}$ & $38.4 \mathrm{ab}$ & $38.1 \mathrm{ab}$ & $2.4 \mathrm{ab}$ & $12.2 \mathrm{c}$ & $12.5 \mathrm{~b}$ & $2.95 \mathrm{c}$ & $2.04 \mathrm{ab}$ \\
\hline Precoce de Colomer & $33.6 \mathrm{ab}$ & $35.6 \mathrm{~cd}$ & $38.8 \mathrm{ab}$ & $39.4 \mathrm{a}$ & $2.8 \mathrm{a}$ & $11.0 \mathrm{~cd}$ & $11.8 \mathrm{bcd}$ & $2.94 \mathrm{c}$ & $2.19 \mathrm{a}$ \\
\hline Rouge de Sernhac & $37.9 \mathrm{a}$ & $39.5 \mathrm{a}$ & $41.6 \mathrm{a}$ & $38.5 \mathrm{a}$ & $2.5 \mathrm{ab}$ & $13.5 \mathrm{~b}$ & $12.1 \mathrm{bc}$ & $3.00 \mathrm{bc}$ & $1.99 \mathrm{ab}$ \\
\hline Tokaloğlu & $30.8 \mathrm{~b}$ & $34.7 \mathrm{~d}$ & $36.3 \mathrm{~b}$ & $35.4 \mathrm{bc}$ & $2.2 \mathrm{bc}$ & $11.4 \mathrm{~cd}$ & $11.0 \mathrm{de}$ & $3.07 \mathrm{bc}$ & $1.90 \mathrm{ab}$ \\
\hline Mean + SE & $33.5 \pm 2.5$ & $36.9 \pm 1.7$ & $38.8 \pm 2.3$ & $37.3 \pm 1.6$ & $2.5 \pm 0.3$ & $12.5 \pm 2.1$ & $12.0 \pm 1.3$ & $3.1 \pm 0.1$ & $2.0 \pm 0.2$ \\
\hline HSD (5\%) & 6.5 & 2.5 & 3.4 & 2.9 & 0.3 & 1.2 & 1.0 & 0.15 & 0.45 \\
\hline
\end{tabular}

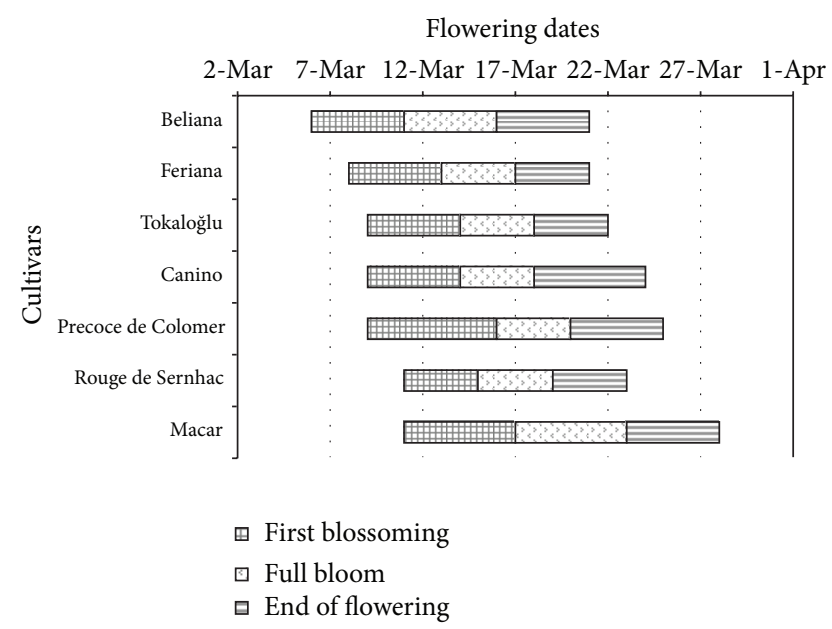

FIGURE 2: Flowering dates of the apricot cultivars (average of four years).

"Beliana" (10.7). In other studies, the flesh/seed ratios of the cultivars varied between 8.9 and 21.8 , and the flesh/seed ratio in "Canino" was generally higher than other cultivars $[3,13]$.

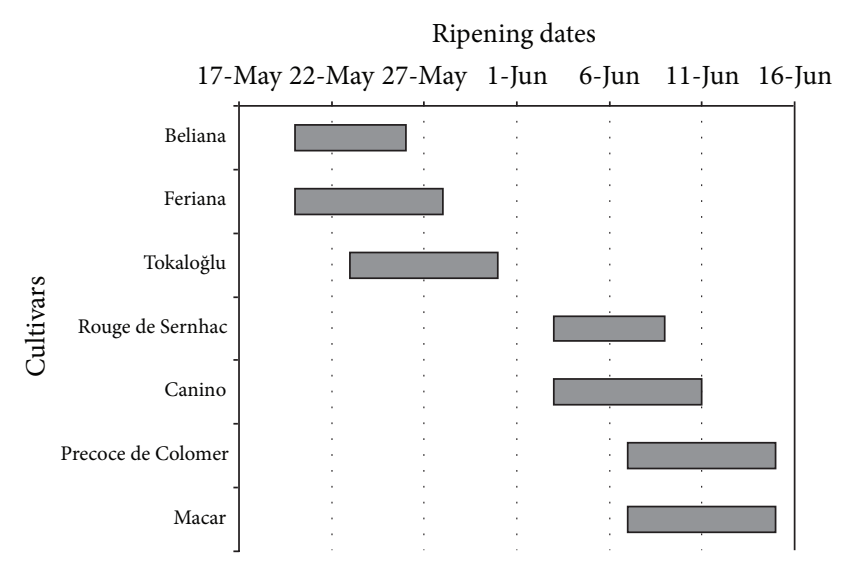

FIGURE 3: Maturation dates of the apricot cultivars (average of four years).

The TSS content is an important quality parameter, influencing notably the fruit taste. TSS content of the apricot cultivars changed between 10.6\% ("Beliana") and $14.5 \%$ ("Canino"). Our data concerning TSS content of the same cultivars were lower than the results obtained by Polat and Yilmaz [13] and higher than those of Polat et al. [3]. 
TABLE 2: Tree trunk diameter, annual shoot length, and yield parameters of the apricot cultivars (average of four years).

\begin{tabular}{|c|c|c|c|c|c|c|c|}
\hline \multirow{2}{*}{ Cultivar } & \multirow{2}{*}{$\begin{array}{c}\text { Tree trunk } \\
\text { diameter }(\mathrm{mm})\end{array}$} & \multirow{2}{*}{$\begin{array}{l}\text { Annual shoot } \\
\text { length }(\mathrm{cm})\end{array}$} & \multicolumn{2}{|c|}{ Yield } & \multirow{2}{*}{$\begin{array}{l}\text { Yield/trunk section } \\
\text { area }\left(\mathrm{kg} / \mathrm{cm}^{2}\right)\end{array}$} & \multicolumn{2}{|c|}{ Cumulative yield } \\
\hline & & & $(\mathrm{kg} /$ tree $)$ & (t/ha) & & $(\mathrm{kg} /$ tree $)$ & $(\mathrm{t} / \mathrm{ha})$ \\
\hline Beliana & $80.5 \mathrm{ab}$ & $66.6 \mathrm{a}$ & $33.1 \mathrm{a}$ & $9.2 \mathrm{~b}$ & $0.94 \mathrm{a}$ & $101.4 \mathrm{~b}$ & $25.6 \mathrm{~b}$ \\
\hline Canino & $55.8 \mathrm{c}$ & $51.2 \mathrm{ab}$ & $16.8 \mathrm{~b}$ & $3.8 \mathrm{c}$ & $0.79 \mathrm{a}$ & $50.6 \mathrm{~d}$ & $10.5 \mathrm{~d}$ \\
\hline Feriana & $90.0 \mathrm{a}$ & $53.2 \mathrm{ab}$ & $19.8 \mathrm{~b}$ & $7.8 \mathrm{~b}$ & $0.34 b c$ & $61.0 \mathrm{c}$ & $17.3 \mathrm{c}$ \\
\hline Macar & $90.1 \mathrm{a}$ & $41.8 \mathrm{~b}$ & $3.1 \mathrm{c}$ & $0.1 \mathrm{~d}$ & $0.06 \mathrm{c}$ & $10.8 \mathrm{f}$ & $2.7 \mathrm{e}$ \\
\hline Precoce de Colomer & $68.9 \mathrm{bc}$ & $65.8 \mathrm{a}$ & $12.6 \mathrm{bc}$ & $4.1 \mathrm{c}$ & $0.36 \mathrm{bc}$ & $35.0 \mathrm{e}$ & $13.4 \mathrm{~cd}$ \\
\hline Rouge de Sernhac & $95.7 \mathrm{a}$ & $50.1 \mathrm{ab}$ & $41.2 \mathrm{a}$ & $14.1 \mathrm{a}$ & $0.61 \mathrm{ab}$ & $125.0 \mathrm{a}$ & $33.6 \mathrm{a}$ \\
\hline Tokaloğlu & $86.8 \mathrm{ab}$ & $47.5 \mathrm{ab}$ & $40.9 \mathrm{a}$ & $13.2 \mathrm{a}$ & $0.65 \mathrm{ab}$ & $121.6 \mathrm{a}$ & $32.0 \mathrm{a}$ \\
\hline Mean + SE & $81.1 \pm 14.1$ & $54.2 \pm 10.0$ & $23.9 \pm 14.7$ & $6.5 \pm 4.1$ & $0.5 \pm 0.3$ & $72.2 \pm 44.4$ & $19.3 \pm 11.5$ \\
\hline HSD (5\%) & 19.4 & 22.6 & 12.1 & 3.5 & 0.35 & 6.8 & 6.3 \\
\hline
\end{tabular}

The highest TSS values were observed in late-ripening apricots, particularly "Canino," "Rouge de Sernhac," and "Macar." Kader [14] considered the mean values of TSS over $10 \%$ as the minimum value for consumer acceptance for apricots, which is the case in our cultivars. The highest $\mathrm{pH}$ was determined in "Beliana" (3.29) whereas the lowest acidity was "Beliana" (1.72\%). "Precoce de Colomer" had the highest acidity (2.19\%). These acidity values were in agreement with previous studies on apricot [11].

3.3. Vegetative Growth and Yield Parameters. Values of tree trunk diameter, annual shoot length, and yield characteristics for the apricot cultivars are shown in Table 2. On the average of four years, "Rouge de Sernhac," "Macar," and "Feriana" had the highest trunk diameter values (95.7, 90.1, and $90.0 \mathrm{~mm}$, resp.). "Beliana" $(66.6 \mathrm{~cm})$ and "Precoce de Colomer" $(65.8 \mathrm{~cm})$ had the highest annual shoot growth values while "Macar" had the lowest $(41.8 \mathrm{~cm})$.

For yield per tree, "Rouge de Sernhac," "Tokaloğlu," and "Beliana" gave the best results (41.2, 40.9, and $33.1 \mathrm{~kg} / \mathrm{tree}$, resp.). The lowest yield per tree was found in "Macar" $(3.13 \mathrm{~kg} /$ tree $)$. The yield values in the study were higher than those of Paydas et al. [15] and Son and Küden [16] but lower than the result of Ayanoglu et al. [17]. "Beliana" $\left(0.94 \mathrm{~kg} / \mathrm{cm}^{2}\right)$ and "Canino" $\left(0.79 \mathrm{~kg} / \mathrm{cm}^{2}\right)$ had the highest yield per unit trunk cross-sectional whereas "Macar" had the lowest $\left(0.06 \mathrm{~kg} / \mathrm{cm}^{2}\right)$.

"Rouge de Sernhac" and "Tokaloğlu" had the highest yield per unit area with 14.1 tons/hectare and 13.2 tons/hectare, respectively, whereas "Macar" had the lowest yield with 0.1 tons/hectare (Table 2). The highest cumulative yield values in both yield per tree and yield per hectare were obtained from "Rouge de Sernhac" (125.0 kg/tree and 33.6, t/ha, resp.) and "Tokaloğlu" (121.6 kg/tree and 32.0, t/ha, resp.). The lowest cumulative yield values were found in "Macar" $(10.8 \mathrm{~kg} /$ tree and 2.7 ton/ha). "Macar" cultivar had the lowest yield parameters in Dörtyol ecological conditions. This can be because the cultivar has higher chilling requirement at the rest period. Actually, the cultivar which had irregular flowering period was lower in shoot length and yield. In addition, Küden and Son [18] indicated that "Beliana" (350 chilling hours), "Feriana" (350 chilling hours), "Precoce de Colomer"(500 chilling hours), and "Canino" (550 chilling hours) cultivars to the chilling requirement grown in the eastern Mediterranean region were sufficient.

Fruiting regularity is the most important parameter for apricot cultivation. Apricot cultivation is greatly restricted by climatic conditions, especially those related to chill accumulation in several growing areas, with a significant influence on productivity. Our results showed that foreign apricots cultivars, especially, "Beliana," "Feriana," and "Rouge de Sernhac," were very well adapted to eastern Mediterranean ecological conditions. In addition, the Mediterranean region for "Precoce de Colomer" was very suitable compared to temperature zone conditions of Turkey [19]. In addition, "Tokaloğlu" which is native Turkish cultivar showed a perfect performance depending on fruit quality and yield parameters compared to foreign cultivars. Apricot cultivars which have lower chill accumulation values can be grown undamaged by late spring frosts in the eastern Mediterranean region.

We can conclude that "Beliana" and "Feriana" cultivars for precocity and "Rouge de Sernhac" and "Tokaloğlu" cultivars for mid-season production with high yields are recommended for planting in Dörtyol, Turkey. Early cultivars in a region which are known for early production should be an important marketing benefit for Turkey.

\section{References}

[1] R. L. Bianco, V. Farina, S. G. Indelicato, F. Filizzola, and P. Agozzino, "Fruit physical, chemical and aromatic attributes of early, intermediate and late apricot cultivars," Journal of the Science of Food and Agriculture, vol. 90, no. 6, pp. 1008-1019, 2010.

[2] A. A. Polat and O. Caliskan, "Determination of growth and fruit quality parameters of some apricot cultivars in subtropical climate conditions of Turkish Mediterranean region," Acta Horticulturae, vol. 862, pp. 323-330, 2010.

[3] A. A. Polat, C. Durgac, Ö. Kamiloglu, and O. Caliskan, "Investigation on the adaptation of some low-chill apricot cultivars to Kirikhan (Turkey) ecological conditions," Acta Hortuculturae, vol. 636, pp. 395-400, 2004.

[4] S. Ercisli, "Apricot culture in Turkey," Scientific Research and Essays, vol. 4, no. 8, pp. 715-719, 2009. 
[5] S. Paydas, N. Kaska, H. Gübbük, and A. A. Polat, "Investigations on the adaptations of some new apricot cultivars to Adana (Turkey) ecological conditions," Journal of Agriculture of Cukurova University, vol. 5, no. 4, pp. 41-48, 1990.

[6] D. Bassi and J. M. Audergon, "Apricot breeding: update and perspectives," Acta Horticulturae, vol. 701, pp. 279-294, 2006.

[7] N. Alburquerque, L. Burgos, M. Sedgley, and J. Egea, "Contributing to the knowledge of the fertilisation process in four apricot cultivars," Scientia Horticulturae, vol. 102, no. 4, pp. 387396, 2004.

[8] C. A. Ledbetter, "Apricots", in Temperature Fruit Crop Breeding, J. F. Hancock, Ed., chapter 2, pp. 39-82, 2008.

[9] SAS Institute, SAS Online Doc., Version 9.1.3. SAS Inst., Cary, NC, USA, 2005.

[10] D. Ruiz and J. Egea, "Phenotypic diversity and relationships of fruit quality traits in apricot (Prunus armeniaca L.) germplasm," Euphytica, vol. 163, no. 1, pp. 143-158, 2008.

[11] A. Heged ũs, R. Engel, L. Abrankó et al., "Antioxidant and antiradical capacities in apricot (Prunus armeniaca L.) fruits: variations from genotypes, years, and analytical methods," Journal of Food Science, vol. 75, no. 9, pp. C722-C730, 2010.

[12] M. Ruml, A. Vuković, and D. Milatović, "Evaluation of different methods for determining growing degree-day thresholds in apricot cultivars," International Journal of Biometeorology, vol. 54, no. 4, pp. 411-422, 2010.

[13] A. A. Polat and M. Yilmaz, "Investigations on the adaptations of some native and foreign apricot cultivars to Adana ecological conditions," Journal of Science and Engineering, vol. 2, no. 1, pp. 127-146, 1988.

[14] A. A. Kader, "Fruit maturity, ripening, and quality relationships," Acta Horticulturae, vol. 484, no. 203, 208 pages, 1999.

[15] S. Paydas, N. Kaska, A. A. Polat, and H. Gübbük, "Investigations on the adaptations of some new apricot cultivars to Adana (Turkey) ecological conditions (in Turkish) (1991-1992 experimental years)," in Proceedings of the Turkish 1st National Horticulture Congress, pp. 465-469, 1992.

[16] L. Son and A. Küden, "Effects of seedling and GF-31 rootstocks on yield and fruit quality of some table apricot cultivars grown in Mersin," Turkish Journal of Agriculture and Forestry, vol. 27, no. 5, pp. 261-267, 2003.

[17] H. Ayanoglu, N. Kaska, and A. Yildiz, "Investigations on the adaptations of early apricot cultivars in Mediterranean region," in Proceedings of the Turkish 2nd National Horticultural Congress, vol. 1, pp. 159-163, 1995.

[18] A. B. Kuden and L. Son, "Researches on peach and nectarines with lower chill requirements," Cukurova University Journal of Agricultural Faculty, vol. 11, pp. 129-138, 1995.

[19] T. Yarılgac and A. Kazankaya, "Adaptation of some apricot cultivars in Van ecological conditions," Kahramanmaras Sutcu Imam University Journal of Science and Engineering, vol. 5, pp. 131-139. 


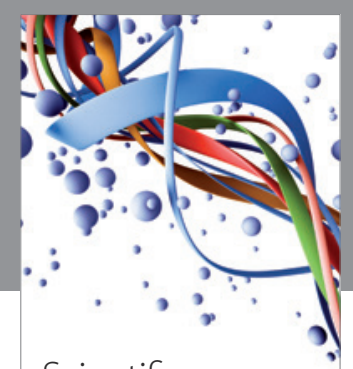

Scientifica
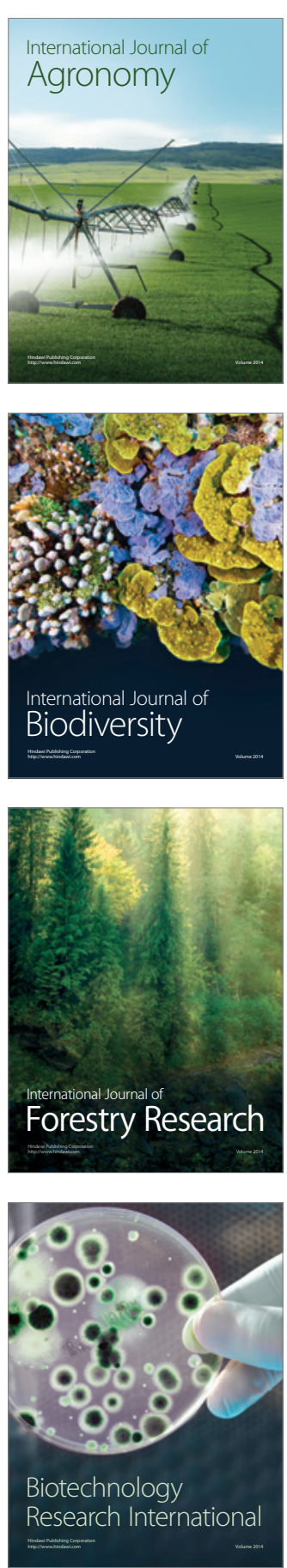
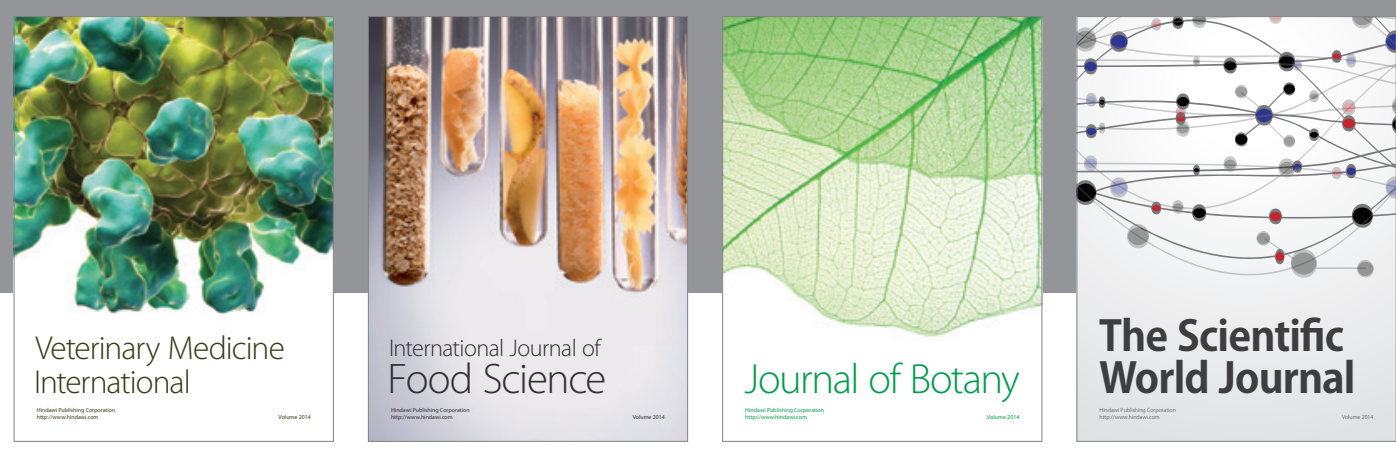

The Scientific World Journal
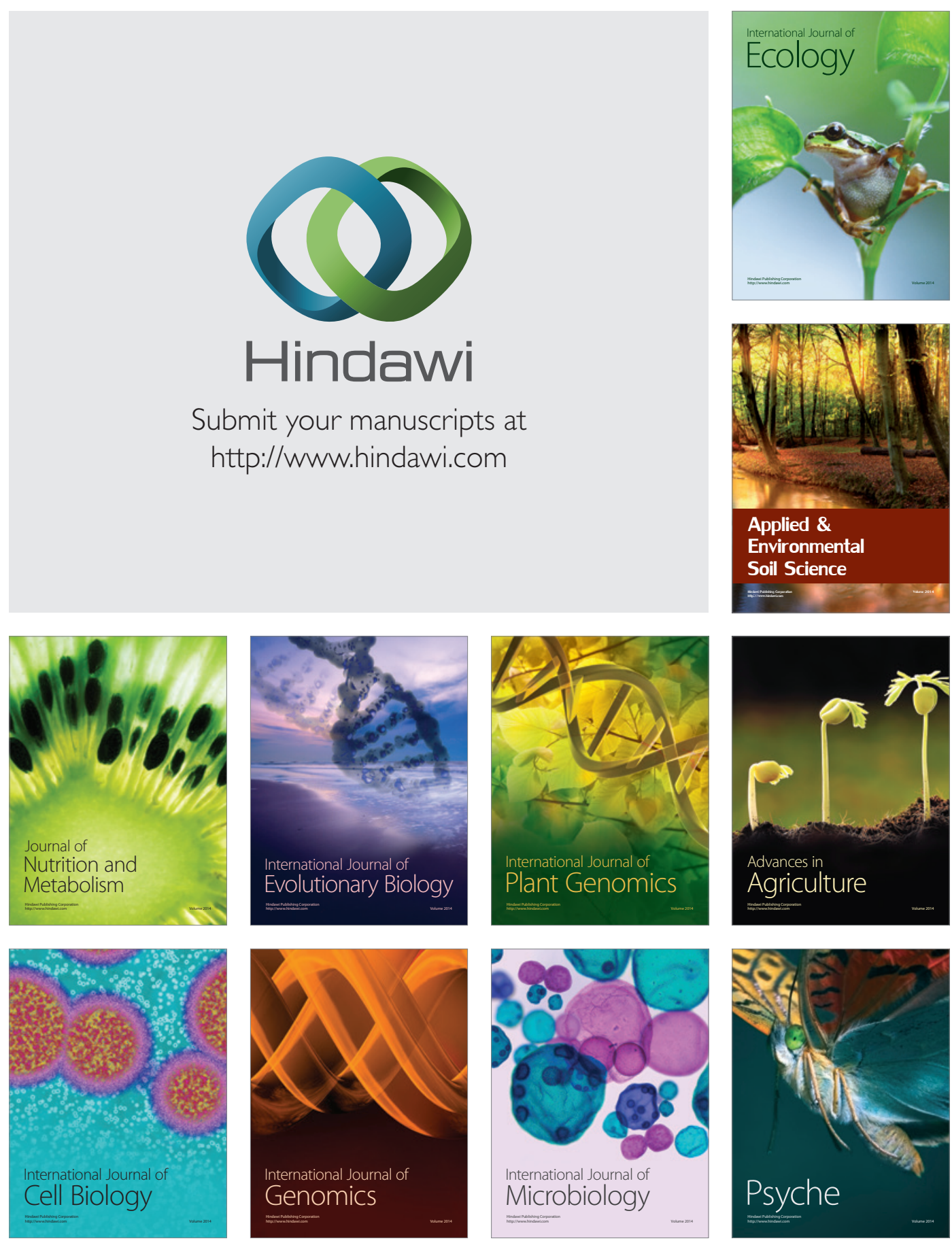